$$
\text { JOES } \begin{aligned}
& \begin{array}{l}
\text { Journal } \\
\text { of Educational } \\
\text { Study }
\end{array} \\
& \text { Etudion }
\end{aligned}
$$

ISSN 2798-0650

Volume 1 Issue 32021

DOI: $10.36663 /$ joes.v1i3.178

\title{
Students' Perception of Google Classroom in Teaching and Learning during Pandemic of Covid-19
}

Ni Putu Juni Ari, Ganesha University of Education, Indonesia niputujuniari18@gmail.com

\begin{abstract}
This study aimed to investigate the students 'perception and challenge in learning by using Google Classroom especially in the current pandemic of Covid-19. The present study used a literature review as the design to collect the data. Related studies about students "perception and challenge on Google Classroom in teaching and learning were analyzed to be described in the present study. The finding of this study showed that students have positive perception toward the use of Google Classroom in learning and it was useful in teaching. However, students 'accessibility and connectivity were the most challenging in learning through Google Classroom during the pandemic.
\end{abstract}

Keywords: Covid-19, Google Classroom, Students 'challenges, Students 'perception

\section{Introduction}

The World Health Organization (WHO) announced the new Corona virus (COVID-19) as the global pandemic on January 30, 2020 (Layali \& Al-Shlowiy, 2020). Covid-19 is a novel corona virus that firstly came from Hubei Province of the People's Republic of China affected countries in the world included in Indonesia with 1.500 cases in 1 April 2020 (Atmojo \& Nugroho, 2020). The Covid-19 caused problem and affects all aspects for people in the world included in education field (Indriani, 2020). Many governments in the world choose to close schools and workplaces in order to limit the spreading of Covid-19 (Layali \& Al-Shlowiy, 2020). Covid-19 also affected Indonesian 'education (Sari et al., 2020). That led Indonesian government' to apply online learning during the pandemic as the steps to reduce the cases of Covid-19 and to protect students, teachers and staffs in the schools.

Covid-19 made the Indonesian government apply the policy of switching conventional teaching and learning to online learning (Agung et al., 2020). The novel Corona virus caused the students to learn and work from home that led to use online learning during the pandemic (Atmojo \& Nugroho, 2020). Online learning is teaching and learning activity that helps students and teachers to exchange knowledge and involve internet technology to use it (Gonzalez \& Louis, 2018) as cited in (Atmojo \& Nugroho, 2020). Furthermore, they stated that online 


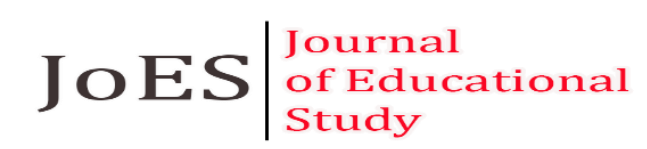

\section{ISSN 2798-0650 \\ Volume 1 Issue 32021 \\ DOI: $10.36663 /$ joes.v1i3.178}

learning is a distance learning that uses electronic devices like tablets, smart phones, laptops, and computers and needs internet connection. The implementation of online learning needs additional media like websites and applications (Indriani, 2020). According to Cakrawati (2017), online learning platforms are tools that use to build students to be independent in learning. There are a lot of friendly applications or platforms that teacher and students could use (Harjanto \& Sumarni, 2019). One of the applications that can use to conduct online learning is Google Classroom(Indriani, 2020).

Google Classroom is one of online platforms that can use in this pandemic to help the teacher and students to conduct online teaching and learning process. Google Classroom is an online platform or tool that helps students to attend classes via online (Hussaini et al., 2020). Harjanto and Sumarni (2019), stated that Google Classroom is a tool that provides various features like teacher's feedback, upcoming task, datelines and announcements which enable students and teachers to do virtual online class interaction and helps teachers to share or create material in forms of documents, videos, pictures, audios for the students which also helps the students do discussion or interaction each other in the discussion board. It has many benefits, through using Google Classroom enable students to take and submit the assignments, take quizzes, Classroom the students can submit and revise their assignments and also check the scores that the teacher gave and also do the task online (Ridho et al., 2019).

That means Google Classroom is useful for education especially in the current situation of covid-19. The pandemic of Covid-19 leads the current phenomenon of some schools in Indonesia to use an online platform like Google Classroom to conduct online teaching and learning. Online learning platforms are the solution to continue teaching and learning during the pandemic of Covid-19 (Suadi, 2021). On the other side, there are some challenges that students face in online learning or learning by using Google Classroom. The learning process in the situation of pandemic Covid-19 is challenging (Sari et al., 2020). Students are struggling with the adaptation and implementation of online learning or learning through Google Classroom. There are some challenges that students face in the online learning or learning by using a platform like Google Classroom. The first is connectivity. Connectivity is essential in implementing online learning included in learning through Google Classroom. The challenge in using Google Classroom refers to connectivity is that Google Classroom cannot be accessed or used without internet connection (Md. Sadequle Islam \& Syeda Afsana Ferdousi, 2019). In addition, some students do not have internet access (Ridho et al., 2019). That means that connectivity is influencing successful teaching and learning through Google Classroom. The second is students 'access to Google Classroom. According to Medford (2017), the implementation of online learning needed facilities such as hardware, software and connectivity but some students who do not have the facility could not access the online learning.

Students are the center of the teaching and learning process. It is important to know students 'perception of Google Classroom to know the effectiveness of teaching and learning process by using Google Classroom. Students 'perception is one of the most important elements in considering the successfulness of online learning (Rahman, 2020). Regarding the current 


\section{JOES $\begin{aligned} & \begin{array}{l}\text { Journal } \\ \text { of Educational } \\ \text { Study }\end{array} \\ & \text { Studionat }\end{aligned}$}

ISSN 2798-0650

Volume 1 Issue 32021

DOI: $10.36663 /$ joes.v1i3.178

phenomenon of learning from home through Google Classroom during the pandemic of Covid19, the present was study conducted to investigate students' perception and challenge on teaching and learning through Google Classroom. It is important to know students' perception of the use of Google classroom in learning to evaluate the effectiveness of teaching and learning by using Google Classroom and the challenge that students face in using Google Classroom during the pandemic. The students can express their opinion or perception toward the use of Google Classroom and the challenge that they found in using Google Classroom as online teaching and learning tool during the pandemic of Covid-19. Through knowing students' perception the teachers can evaluate the effectiveness of teaching and learning through Google classroom and know which needs to change and improve in teaching and learning process so that the teaching and learning process through Google Classroom would be effective (Ridho et al., 2019). Related study had been conducted by Hussaini et al., (2020), that showed Google Classroom is an effective digital tool to improve students attentiveness in learning and it helped the students become more active in teaching and learning but the internet connection was the challenge that made them late in submitting their assignment. Thus, the present study conducted to investigate students' perception and challenge on Google Classroom in teaching and learning during the pandemic.

\section{Method}

This study used literature study in collecting data. Various studies related to the use of Google Classroom during the pandemic of Covid-19 were analyzed to identify students 'perception and challenge in using Google Classroom in the pandemic. Those studies were collected from online publishing and research. The focused analysis of this study was the students 'perception and challenge in learning through Google Classroom during the pandemic and important information about the use of Google Classroom.

\section{Findings and Discussions}

\section{Students' perception on Google Classroom in teaching and learning during the pandemic of Covid-19.}

In this era, many schools use technology in teaching and learning by using the tool of Information and Communication Technologies (Harjanto \& Sumarni, 2019). That becomes stronger in the current situation of the pandemic of Covid-19. The pandemic of Covid-19 has impacted the education system (Naciri et al., 2020). Furthermore, they stated many schools in the world have closed in order to reduce the spreading of Covid-19. This situation leads students and teachers to use virtual teaching and learning by using some platforms and one of them is through Google Classroom. It is one of the online platforms that enable students and teachers use to conduct online teaching and learning (Harjanto \& Sumarni, 2019). Furthermore, they stated that Google Classroom is the tool that provides various features that enable students and teachers to do online interaction. In this situation, knowing how students' perception on the use of Google 


\section{J OES $\begin{aligned} & \begin{array}{l}\text { Journal } \\ \text { of Educational } \\ \text { Study }\end{array}\end{aligned}$}

ISSN 2798-0650

Volume 1 Issue 32021

DOI: $10.36663 /$ joes.v1i3.178

classroom is important to know the effectiveness of Google Classroom, to evaluate and improve the effectiveness of teaching and learning through Google classroom.

Google Classroom is an application that is easily accessed by using Smartphone or computer that supports teaching and learning process. The teachers just need to share the class code to create a group and let the students join the online class (Ridho et al., 2019). According to Negara (2018), Google Classroom has some advantages such as first accessible from all devices and easy to use which means Google Classroom can use from chrome, from all computers, phones and tablets. The second is effective communication and sharing which means the teacher can create an announcement and share assignments by Google Docs and the students can access it immediately. The third is effective in giving feedback. Google Classroom helps the teachers to give feedback to the students through comments and remarks. The fourth is the good commenting system. Google Classroom provides the students and the teacher to comment on the subject as the discussion forum.

There was some students' perception of Google Classroom in teaching and learning during the pandemic of Covid-19. A finding by Indriani (2020), noted that students had positive perception toward Google Classroom in learning. Furthermore, she stated that Google Classroom is a platform that has many benefits for students and teacher especially in the pandemic of Covid19 where Google Classroom is effective and it helped the students to learn in different places. It is also noted in the finding by Ridho et al., (2019), revealed that the students perceived positive perception of Google Classroom. The effective platform helped the students actively participate in online discussions and tasks. It is also helped the students to learn anywhere, anytime, and easy to use in learning such as easy to take and submitted assignments, quiz and do tasks online.

Students feel satisfied and enjoyed learning through Google Classroom because it is useful in delivering the material, submitted their assignment, get feedback and instruction, and increased students 'motivation. A finding study by Mualim et al., (2019), stated that students enjoyed learning through Google Classroom and it is useful in delivering the materials but the students had some challenges in learning through Google Classroom such as the problem in their devices, internet connection, and lack of instruction in Google Classroom. The finding in a study by Shaharanee et al., (2016), showed the students were satisfied on the use of Google Classroom in teaching and learning activities. In addition, the finding by Salam (2020), stated that students satisfied in learning by using Google Classroom because it helped the students to submitted their assignments on time, get feedback from their teacher, course descriptions and communication with their instructors. Another study by Mariadi et al., (2019), that revealed good perception of the students on Google Classroom in submitting their assignment in translation subject. That means that students had good perception of Google Classroom as the media for submitting their assignment in translation subject. The finding by Wardani (2020), showed the implementation of learning by using Google Classroom can improve students 'motivation and students 'participation during the teaching and learning through Google Classroom. Another finding by Widodo \& Slamet (2020), stated that students have good respond toward Google Classroom 


\section{JoES $\begin{aligned} & \begin{array}{l}\text { Journal } \\ \text { of Educational } \\ \text { Study }\end{array} \\ & \text { Studion }\end{aligned}$}

ISSN 2798-0650

Volume 1 Issue 32021

DOI: $10.36663 /$ joes.v1i3.178

because it is a useful and effective tool in submitting students 'task and become the resolution in the issue of Covid-19.

\section{Students' challenges in using Google Classroom in teaching and learning}

The implementation of online learning or learning by using online platform like Google Classroom has some challenges. There are some challenges in learning by using Google Classroom or online learning such as:

\section{a. Poor internet connection and accessibility}

Internet connection and accessibility are important factors in conducting online learning included in learning through Google Classroom. According to Medford (2017), the implementation of online learning needed facilities like hardware, software and connectivity but some students who do not have the facility like a computer and internet connection could not access online learning. The other challenge in Google Classroom was that Google Classroom cannot be accessed or used without internet connection (Md. Sadequle Islam \& Syeda Afsana Ferdousi, 2019). There are some students that do not have access to the internet (Ridho et al., 2019).

b. Students lack knowledge in using Google Classroom.

Some students might have difficulty in operating/using Google Classroom in the learning process. There are some disadvantages or limitations of Google Classroom. Google Classroom has some disadvantages, namely the problem of time consuming, the problem in following the Google Classroom' procedures, plagiarism, and some students could not access to the internet (Ridho et al., 2019).

\section{c. Poor communication}

According to Medford (2017) one of the challenges in online learning is poor communication. Furthermore, they stated that Poor connection while doing online learning could make misinterpretation between the teacher and the students that affected teaching and learning process and the students 'outcome. In addition, one of the weaknesses in using Google Classroom is the lack of students' and teachers' interception in the real world (Mulyadi, 2018).

\section{d. Lack of motivation}

According to Mulyadi (2018), one of the weaknesses in using Google Classroom is the lack of students' motivation. In addition, According to Medford (2017), online learning could make the students have lack motivation because they were distracted to the other thing. Students who learn through online learning have to learn in their own space. That makes some students find difficulty in time management and procrastinate.

e. The feeling of isolated

According to Medford (2017) one of the challenges in online learning is the feeling of isolated. Furthermore, they stated that the development of technology enables students to keep in 


\section{JOES $\begin{aligned} & \begin{array}{l}\text { Journal } \\ \text { of Educational } \\ \text { Study }\end{array}\end{aligned}$}

ISSN 2798-0650

Volume 1 Issue 32021

DOI: $10.36663 /$ joes.v1i3.178

touch or chatting with their online friends but they could not meet and talk to each other in real life that made them feel isolate and stress which can be the factor that made them drop out from school.

\section{Conclusions and Suggestions}

The goals of the study were to analyze the students' perception and challenges in using Google Classroom in teaching and learning during the pandemic by using literature study in collecting data. The findings showed that students had positive perception of Google Classroom in teaching and learning during the pandemic. In addition, the students also found some challenges in learning through Google Classroom such as the poor internet connection and accessibility, students lack knowledge in using Google Classroom, poor communication, lack of motivation, and the feeling of isolated. Based on the finding and discussion above, it can conclude that Google Classroom is a useful application in teaching and learning. The students have positive perception of Google Classroom in teaching and learning. Even though there is positive perception from the students in learning through Google Classroom, however, there were some challenges that students face in using Google Classroom which the most challenges are in terms of students 'accessibility and connectivity.

The suggestion that can give to the teachers is that the teachers should know the students' perception of Google Classroom in teaching and learning and the challenges that students faced in learning through Google Classroom so that the teachers can evaluate the effectiveness of teaching and learning through Google Classroom during the pandemic.

\section{References}

Agung, A. S. S. N., Surtikanti, M. W., \& Quinones, C. A. (2020). Students' perception of online learning during COVID-19 pandemic: A case study on the English students of STKIP Pamane Talino. Journal of Social Sciences and Humanities, 10(2), 225-235.

Atmojo, A. E. P., \& Nugroho, A. (2020). EFL Classes Must Go Online! Teaching Activities and Challenges during COVID-19 Pandemic in Indonesia. Register Journal, 13(1), 49-76.

Cakrawati, L. M. (2017). Students' Perceptions on the Use of Online Learning Platforms in Efl Classroom. English Language Teaching and Technology Journal (ELT-Tech Journal, 1(1), 22-30.

Harjanto, A. S., \& Sumarni, S. (2019). Teacher's Experiences on The Use of Google Classroom. 3rd English Language and Literature International Conference (ELLiC), 3, 172-178.

Hussaini, I., Ibrahim, S., Wali, B., Libata, I., \& Musa, U. (2020). Effectiveness of Google Classroom as a Digital Tool in Teaching a nd Learning : Students 'Perceptions. IV(April), 51-54.

Indriani, L. (2020). THE EFL Students 'Perception in Using Google Classroom For English Learning During Pandemic. 3, 328-335. 


\section{JOES $\mid \begin{aligned} & \text { Journal } \\ & \text { of Educational } \\ & \text { Study }\end{aligned}$}

ISSN 2798-0650

Volume 1 Issue 32021

DOI: $10.36663 /$ joes.v1i3.178

Layali, K., \& Al-Shlowiy, A. (2020). Students' Perceptions of e-Learning for ESL / EFL in Saudi Universities and their Implications during Coronavirus Pandemic: A Review of Literature. International Journal of English Language \& Translation Studies, 8(1), 64-72.

Mariadi, T., Handayani, F., \& Sepyanda, M. (2019). The Analysis of Students' Perception on the Use of Google Classroom in Submitting Their Assignment in Translation Subject on the Third Year Students of English Department of FKIP UMMY Solok. English Language and Pedagogy, 4(1), 26-34.

Md. Sadequle Islam, \& Syeda Afsana Ferdousi. (2019). Techno-Aide Google Classroom for Learning English: Prospects \& Challenges. Journal on Today's Ideas - Tomorrow's Technologies, 7(2), 106-117.

Medford, A. R. L. (2017). Online learning. Quality in Primary Care, 12(1), 32-34.

Naciri, A., Baba, M. A., Achbani, A., \& Kharbach, A. (2020). Mobile Learning in Higher Education: Unavoidable Alternative during COVID-19. Aquademia, 4(1), ep20016.

Negara, I. M. (2018). Students Perception: the Use of Google Classroom in Teaching-Learning Process. Spectral, 4(1), 012-025.

Rahman, K. (2020). Learning Amid Crisis: Efl Students' Perception on Online Learning During Covid-19 Outbreak. Learning Amid Crisis, 6(2), 179.

Ridho, D. M., Sawitri, I. D., \& Amatulloh, N. A. (2019). Students ' Perception Toward Google Classroom Application in Efl Classroom. Seminar Nasional Pendidikan, 1325-1332.

Salam, U. (2020). The Students' Use of Google Classroom in Learning English. JPI (Jurnal Pendidikan Indonesia), 9(4), 628-638.

Sari, W. P., Pramesti, D., \& Kusuma, A. I. (2020). Student's perception of online learning in pandemic. Proceding “International Webinar on Education 2020," 201-207.

Shaharanee, I. N. M., Jamil, J. M., \& Rodzi, A. S. S. M. (2016). The application of Google Classroom as a tool for teaching and learning. Journal of Telecommunication, Electronic and Computer Engineering, 8(10), 5-8.

Suadi, S. (2021). Students' Perceptions of the Use of Zoom and Whatsapp in Elt Amidst Covid19 Pandemic. SALEE: Study of Applied Linguistics and English Education, 2(01 SEArticles), 51-64.

Wardani, W. S. (2020). Google Classroom dapat meningkatkan motivasi belajar siswa kelas VI Tema 5 SD Negeri 1 Purwanegara di Masa Pandemi.3(3).

Widodo, J. P., \& Slamet, J. (2020). Students' Perception Toward Google Classroom as ELearning Tool. Malaysian Palm Oil Council (MPOC), 21(1), 1-9. 